\title{
Responses of two temperate evergreen Nothofagus species to sudden and gradual waterlogging: relationships with distribution patterns
}

\author{
Respuestas de dos especies siempreverdes de Nothofagus al anegamiento gradual \\ y repentino: relaciones con patrones de distribución
}

\author{
FRIDA PIPER ${ }^{1,2}, *$, ALEJANDRA ZÚÑIIGA-FEEST ${ }^{3}$, PAULINA ROJAS $^{3}$, MIREN ALBERDI $^{4}$, LUIS J. CORCUERA $^{1}$ \\ \& CHRISTOPHER H. LUSK 1,5

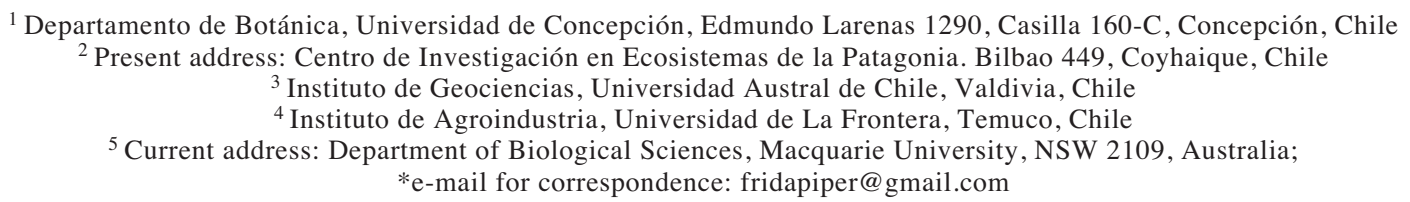

\begin{abstract}
The effects of gradual waterlogging on trees have been little studied. The temperate evergreens Nothofagus nitida and $N$. dombeyi are differentially distributed on soil moisture gradients, only the former being common on poorly-drained sites. We compared the relative height growth rate $\left(\mathrm{RGR}_{\mathrm{H}}\right)$ and foliage loss of seedlings subjected experimentally to normal drainage (soil at field capacity), sudden waterlogging and gradual waterlogging for two months to determine which waterlogging regime more accurately predicts interspecific differences in tolerance, as evident from natural distributions. $\mathrm{RGR}_{\mathrm{H}}$ was similar between species but differed between treatments (normal watering $>$ gradual waterlogging $=$ sudden waterlogging). Sudden waterlogging caused massive foliage loss in the two species, but gradual waterlogging caused much greater foliage loss in $N$. dombeyi than in $N$. nitida, indicating some degree of acclimation by the latter species. Linear regressions indicated that $\mathrm{RGR}_{\mathrm{H}}$ was negatively affected by foliage loss in both species, without differences between them. Since no difference in $\mathrm{RGR}_{\mathrm{H}}$ was found between species in the waterlogging treatments, but yet in foliage loss, other mechanisms may be involved in the short term growth reduction of $N$. nitida. Effects of waterlogging on long-term performance in the field were evaluated by reciprocal transplants between a poorly-drained site naturally occupied by $N$. nitida, and a well drained site naturally occupied by $N$. dombeyi. After two growing seasons, $N$. dombeyi had significantly lower specific leaf area (SLA) and $\mathrm{RGR}_{\mathrm{H}}$, at the poorly drained site than at its original site. At the poorly drained site $N$. nitida achieved $100 \%$ survival, compared with $73.5 \%$ in $N$. dombeyi. Reduced growth and survival of $N$. dombeyi associated with the negative effects on carbon gain of extensive foliage loss and reduced SLA may thus exclude it from the wetter sites. We conclude that tolerance may be better predicted from responses to gradual, rather than sudden waterlogging.
\end{abstract}

Key words: Nothofagus, reciprocal transplants, seedling growth, temperate rainforest.

\section{RESUMEN}

Los efectos del anegamiento gradual sobre las especies arbóreas han sido poco estudiados. Nothofagus nitida y $N$. dombeyi son especies siempreverdes templadas diferencialmente distribuidas sobre gradientes de humedad del suelo; solo la primera es común en sitios de drenaje pobre. Comparamos la tasa de crecimiento relativo $\left(\mathrm{RGR}_{\mathrm{H}}\right)$ y la pérdida foliar de plántulas de dos a tres años sujetas experimentalmente durante dos meses a drenaje normal (humedad del suelo en capacidad de campo), anegamiento repentino y anegamiento gradual, para determinar qué régimen de anegamiento predice mejor diferencias interespecíficas en tolerancia, las cuales son sugeridas desde las distribuciones naturales. $\mathrm{RGR}_{\mathrm{H}}$ resultó similar entre las especies pero difirió entre tratamientos (controles $>$ anegamiento gradual $=$ anegamiento repentino). El anegamiento repentino causó una masiva pérdida foliar en ambas especies, pero el anegamiento gradual causó mayor pérdida en $N$. dombeyi que en $N$. nitida indicando cierto grado de aclimatación por parte de esta última. Regresiones lineares indicaron que $\mathrm{RGR}_{\mathrm{H}}$ fue negativamente afectado por la pérdida foliar en ambas especies pero más en $N$. dombeyi, sugiriendo que otro mecanismo causó el decrecimiento de $\mathrm{RGR}_{\mathrm{H}}$ en $N$. nitida. Para evaluar el efecto del anegamiento sobre el desempeño en el largo plazo, se realizaron trasplantes recíprocos en la cordillera de la Costa entre un sitio de drenaje limitado dominado por $N$. nitida y $\sin N$. dombeyi, y un sitio sin limitaciones de drenaje dominado por $N$. dombeyi y $\sin N$. nitida. Luego de dos temporadas de 
crecimiento, $N$. dombeyi presentó menores área foliar específica (SLA) y $\mathrm{RGR}_{\mathrm{H}}$ en el sitio de drenaje limitado que en su sitio original. La sobrevivencia en el sitio de drenaje pobre fue $100 \%$ para $N$. nitida y $73,5 \%$ para $N$. dombeyi. Reducidos crecimiento y sobrevivencia de $N$. dombeyi asociados a los efectos negativos de masiva pérdida foliar y reducida SLA podrían excluir a esta especie de sitios muy húmedos. Concluimos que la tolerancia puede predecirse mejor desde respuestas al anegamiento gradual, más que al anegamiento repentino.

Palabras clave: crecimiento de plántulas, Nothofagus, bosque lluvioso templado, trasplantes recíprocos .

\section{INTRODUCTION}

Tolerance of waterlogging may be an important determinant of tree species' distributions (Niinemets \& Valladares 2006, Pryor et al. 2006). Since waterlogging damage decreases as ontogeny progresses (Kozlowski 1997), knowing how seedlings respond to flooding becomes very relevant to understanding processes involved in community structure. The energy crisis associated with inhibition of root respiration by anoxia is one of the main problems caused by waterlogging (Gibbs \& Greenway 2003). Under natural conditions waterlogging is often an intermittent phenomenon, associated with diurnal and/or seasonal variations in precipitation and evapotranspiration (Hansen 2001, Thiers et al. 2007). The onset of flooding often occurs gradually, or as a series of pulses of increasing intensity and/or duration, giving scope for expression of plant acclimation responses to the associated stresses (Gibbs \& Greenway 2003). A gradual decrease in soil oxygen allows the expression of particular features related to anoxia tolerance or avoidance, such as new adventitious roots and the activation of fermentation pathways (Blom et al. 1994, Gibbs \& Greenway 2003, Igamberdiev \& Hill 2004). However, most studies of the effects of waterlogging on trees from temperate forests have involved sudden exposure to continuous submersion of roots, which does not necessarily resemble the conditions naturally experienced by these species (Tang \& Kozlowski 1984, Angelov et al. 1996, Gravatt \& Kirby 1998).

Apparent tolerance of waterlogging may change according to the experimental approach used (Gibbs \& Greenway 2003). For example, in herbaceous plants tolerance depends to some degree on whether the onset of anoxia is progressive or sudden (Waters et al. 1991, Xia \& Saglio 1992, Germain et al. 1997). Although the evidence for trees is scarce, it also suggests that responses to waterlogging could vary depending on the nature of the experiment (Pryor et al. 2006). Premature leaf abscission and reduced growth are the main symptoms of waterlogging in susceptible species (Kozlowski 1997, Gravatt \& Kirby 1998, Schmull \& Thomas 2000). A decrease specific leaf area has also been reported as a long-term response of susceptible species to waterlogging (Lenssen et al. 2003).

Nothofagus nitida (Phil.) Krasser and $N$. dombeyi (Mirb.) Blume are two closely-related evergreens from the Chilean temperate rainforest that are differentially distributed along soil moisture gradients. The former grows on mesic sites, including sites with brief summer drought (Donoso 1981) whereas the latter is restricted to sites with oceanic climates and permanently moist soils, sometimes poorlydrained (Holdgate 1961, Veblen \& Schlegel 1982). They are rarely found growing together (Weinberger 1973) in spite of their proximity in life history traits (McQueen 1976, Veblen et al. 1996) and phylogeny (Romero 1986, Hill \& Jordan 1993). In the areas were these species coexist, although rarely sharing sites, hypoxia or anoxia during brief periods would be more common than sudden anoxia events (Holdgate 1961, Debus 1987, Hansen 2001).

Here we compare the effects of gradual and sudden submersion regimes on growth and leaf loss of two species of contrasting waterlogging tolerance. We simulated natural onset of waterlogging in a short-term experiment by applying a series of submersion pulses of increasing duration, an approach not taken before with tree species. A second aim was to examine the consistency between short-term responses and long-term performance, evaluating survival and growth of $N$. dombeyi and $N$. nitida under natural long-term waterlogging conditions. The long-term waterlogging experiment consisted of a reciprocal transplant experiment which was carried out for two growing seasons. 


\section{MATERIAL AND METHODS}

\section{Reciprocal transplants}

The transplants were performed among two sites on the western slope of the coastal range, Chile. One of the sites is dominated by $N$. dombeyi, located at $80 \mathrm{~m}$ of altitude (39 $58^{\circ} 02^{\prime}$ " S, 73'33'39" W), and characterized by sandy soils without drainage limitations (hereafter the "well drained" site). The other site is dominated by a mixed forest of $N$. nitida, located at $350 \mathrm{~m}$ of altitude $\left(39^{\circ} 59^{\prime} 40^{\prime \prime} \mathrm{S}\right.$, $\left.73^{\circ} 34^{\prime} 12^{\prime \prime} \mathrm{W}\right)$. This site is characterized by predominantly clay soils (Piper et al. 2007). The contrasting particle sizes composition of these soils determines differences in drainage indicated by the levels of water retention capacity associated to extreme water potentials. For a water potential of $-1.5 \mathrm{MPa}$, humidity retention were 16 and $5.2 \%$ for $N$. nitida and $N$. dombeyi site soils, respectively, whereas for a water potential of $-0.1 \mathrm{MPa}$, the values were 30.1 and $17 \%$.

In July 2004, 49 seedlings of $N$. dombeyi and 50 of $N$. nitida were cross-transplanted between the two sites. Another 50 seedlings of $N$. dombeyi and 36 of $N$. nitida were transplanted within their site of origin, as a transplant control. The transplants were carried out in a random design. Seedlings ranked heights between $25-40 \mathrm{~cm}$ and were selected from sites with 40-60 \% canopy openness. In February 2006, survivors were counted, excavated and taken to the laboratory (Instituto de Botánica, Universidad Austral de Chile in Valdivia) within three hours. There, growth and specific leaf area measurements were carried out.

Height growth of the last season was registered in 18 individuals of each species at the poorly drained site and in five individuals of each species at the well drained site. This parameter was easily measurable because of scars left alter each growth pulse in these species. Those numbers of individuals was selected procuring to choose the most similar individuals in initial size. The initial heights were marginally similar for both species at 350 m of altitude $(28.3 \pm 1.7 \mathrm{~cm}$ for $N$. dombeyi and $33 \pm 1.9 \mathrm{~cm}$ for N. nitida; $\mathrm{P}=0.074$, Student $\mathrm{t}-$ test $)$ and at $80 \mathrm{~m}$ of altitude $(20 \pm 2.24 \mathrm{~cm}$ for $N$. dombeyi and $26 \pm 0.46 \mathrm{~cm}$ for $N$. nitida $; \mathrm{P}=$
0.06, Student t-test). To minimize the effect of initial sizes marginally different on growth, relative height growth rate was calculated $\left[\left(\mathrm{RGR}_{\mathrm{H}}=\left(\mathrm{Ln} \mathrm{H}_{\text {final }}-\mathrm{Ln} \mathrm{H}_{\text {initial }}\right)\right.\right.$ time $^{-1}$, in $\ln \mathrm{cm}$ $(\text { ln } \mathrm{cm})^{-1} \mathrm{y}^{-1}$ ] for the last growth season. Specific leaf area (SLA) was calculated for five plants from each species and altitude, as the ratio between the area of all leaves of the plant and their dry mass. Growth and SLA data were compared among sites and species by two-way ANOVAs, using a multiple comparison of means test when the differences were significant (Tukey's HSD post-hoc test). Survival was compared by resampling the combined survival data (alive $=1$, dead $=0$ ) for the two species, to determine the probability that the observed difference in survival could arise by chance between two samples taken from the same population (Resampling Stats, Inc, Arlington, Virginia, USA). This was done as a two-tailed test, scoring the absolute difference between each of 10,000 pairs of samples obtained by randomly sampling the combined file, with replacement.

\section{Waterlogging experiment}

In July 2005, 25 seedlings of both species were carefully taken out from the same sites where the reciprocal transplants were performed and were carried to a greenhouse located at Universidad Austral in Valdivia. Individuals $16-30 \mathrm{~cm}$ tall with minimal leaf damage were used. These plants were placed in pots filled with a mixture 40: 20: 30: 10 of peat moss: pine cortex: organic soil: sand (v/v) and kept in well watered conditions for 10 weeks. Fertilizer was added weekly (Phostrogen $0.1 \mathrm{~g} \mathrm{~L}^{-1}$ : 14 , $10,22(\mathrm{~N}, \mathrm{P}, \mathrm{K})$ plus $\mathrm{Mg}, \mathrm{S}$ and chelated trace elements).

Groups of six plants of the two species were gradually or suddenly flooded by submerging pots up to the soil surface. A third group of six plants was kept as a control in a well drained state, similar to the period before the experiment. The gradual waterlogging treatment consisted in progressively increasing the duration of submersion pulses from 1 to 24 $\mathrm{h}$ per day during the first 18 days of a twomonth experimental period (Fig. 1). During the flood-free periods we let pots drain normally. The sudden waterlogging treatment consisted of continuous submersion for two months. 
Time of waterlogging (hour day ${ }^{-1}$ )

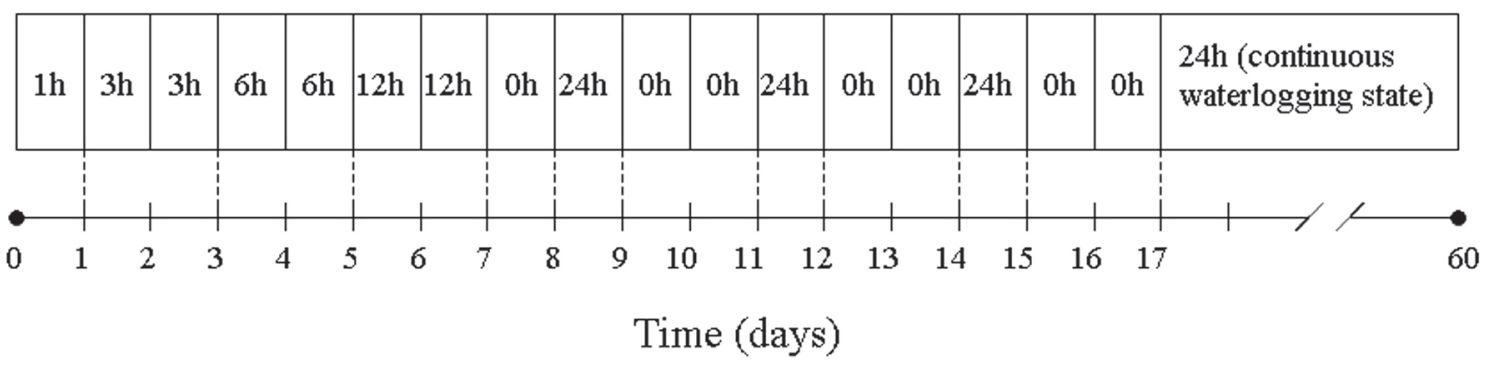

Fig.1: Temporal distribution and duration of daily episodes of submersion during the first 17 days of a gradual waterlogging treatment in a two-month experiment.

Distribución temporal y duración de episodios diarios de submersión durante los primeros 17 días de un tratamiento de anegamiento gradual en un experimento de dos meses de duración.

$\mathrm{RGR}_{\mathrm{H}}\left(\ln \mathrm{cm}\left(\operatorname{ln~} \mathrm{cm}^{-1}\right) \mathrm{mo}^{-1}\right)$ was calculated by measuring the height increment of all seedlings per treatment, during the experimental period. During the experimental period shed leaves were collected from all individuals per treatment, and dried at $70{ }^{\circ} \mathrm{C}$ to a constant dry weight. At the end of the experiment the leaves that remained on the plants were dried and weighed. Total foliage mass was obtained by adding the dry weights of naturally shed leaves and leaves that remained on the plant. A two-way ANOVA was used to compare the effect of waterlogging on leaf shedding and $\mathrm{RGR}_{\mathrm{H}}$, with "species" and "waterlogging treatment" as fixed effects. Multiple comparison of means test was used when the differences were significant (Tukey's HSD post-hoc test). Linear regressions were used to examine the effect of leaf shedding on growth, and ANCOVA was used to test interespecific differences in these regressions, where "species" was the factor and "foliage loss" the covariate (JMP 4.0.4).

\section{RESULTS}

\section{Reciprocal transplant}

$\mathrm{RGR}_{\mathrm{H}}$ was lower at the poorly drained site than at the well drained one (Table 1, Fig. 2). The significant interaction between treatment and species showed in the ANOVA was entirely due to the lower $\mathrm{RGR}_{\mathrm{H}}$ of $N$. dombeyi at the poorly drained site (Tukey, $\mathrm{P}=0.05$ ), where $N$. nitida grew $32 \%$ more than $N$. dombeyi. Hence, the significant effect of site on $\mathrm{RGR}_{\mathrm{H}}$ (Table 1) was mainly due to the variation in growth of $N$. dombeyi between altitudes.

\section{TABLE 1}

Two-way ANOVA showing the effects of site and species on growth $\left(\mathrm{RGR}_{\mathrm{H}}\right)$ by seedlings of

Nothofagus dombeyi and $N$. nitida from a reciprocal transplant experiment at the coastal range of Chile

ANOVA de dos vías mostrando el efecto del sitio y de la especie sobre el crecimiento $\left(\mathrm{RGR}_{\mathrm{H}}\right)$ de plántulas de Nothofagus dombeyi y N. nitida pertenecientes a un experimento de trasplante recíproco en la Cordillera de la Costa de Chile

\begin{tabular}{lcccc}
\hline Factor & $\begin{array}{c}\text { Response } \\
\text { variable }\end{array}$ & $\begin{array}{c}\text { Degrees } \\
\text { of freedom }\end{array}$ & F-value & P-value \\
\hline Site & RGR $_{\mathrm{H}}$ & 1 & 17.5 & $<0.001$ \\
Species & & 1 & 0.54 & 0.46 \\
Site ${ }^{*}$ species & & 1 & 3.98 & 0.05 \\
Error & & 44 & & \\
Site & SLA & 1 & 7.453 & 0.014 \\
Species & & 1 & 52.95 & $<0.001$ \\
Site $*$ species & & 1 & 5.94 & 0.026 \\
Error & & 20 & & \\
\hline
\end{tabular}

A contrasting pattern of variation in SLA was observed for each species between sites, which explained the significant interaction between factors in the ANOVA (Table 1). SLA of $N$. nitida was similar at the two sites (Tukey, 
$\mathrm{P}=0.842$ ), whereas that of $N$. dombeyi was $25 \%$ lower at the poorly drained site than at well drained one (Tukey, $\mathrm{P}=0.002$ ). The significant effect of the site on SLA showed by the ANOVA was entirely due to variation in $N$. dombeyi. The significant effect of the species on SLA was due to the higher values in $N$. dombeyi than in N. nitida at both sites (Table 1, Fig. 3).

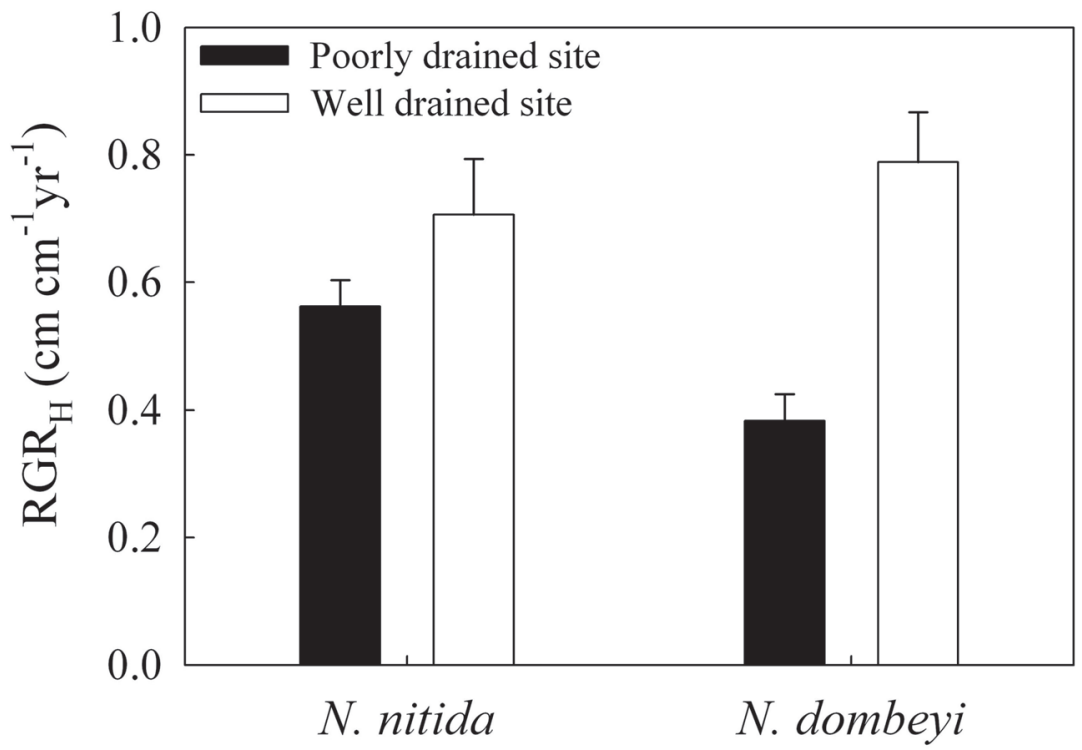

Fig. 2: Relative height growth rate of seedlings of Nothofagus dombeyi and N. nitida from a reciprocal transplant experiment between two sites characterized by differential soil drainage at the coastal range south of Valdivia, Chile.

Tasa de crecimiento relativo en altura de plántulas de Nothofagus dombeyi y N. nitida pertenecientes a un experimento de trasplantes recíprocos entre dos sitios caracterizados por drenaje diferente en la Cordillera de la Costa, Chile.

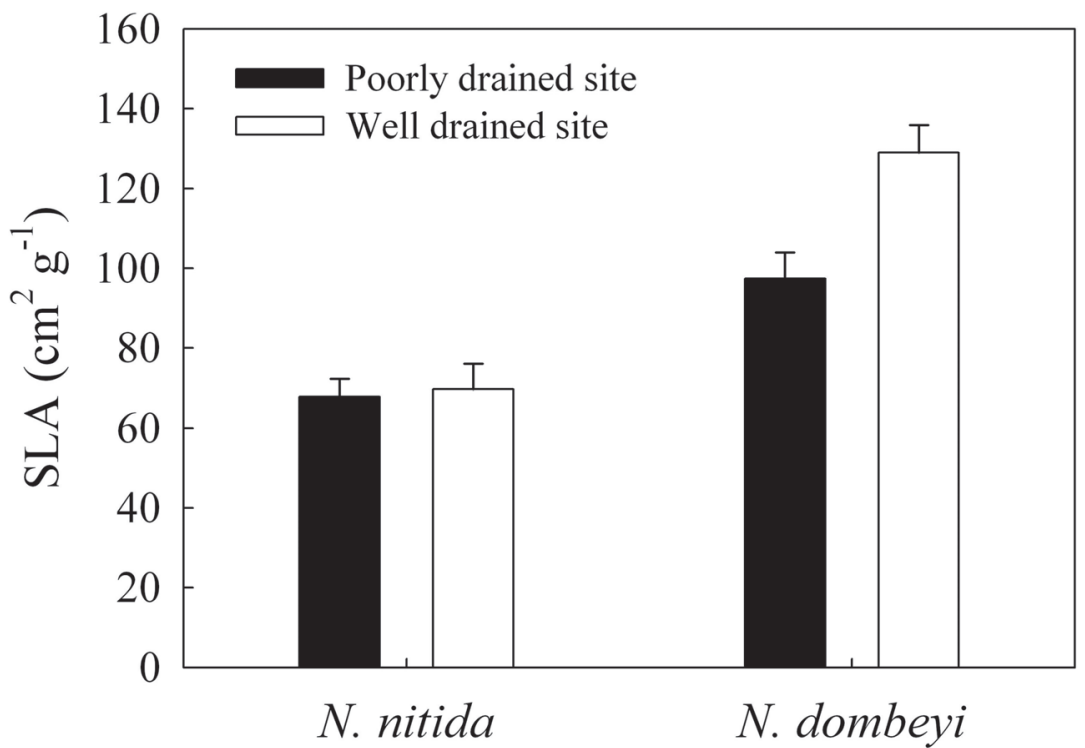

Fig. 3: Specific leaf area of seedlings of Nothofagus dombeyi and N. nitida from a reciprocal transplant experiment between two sites characterized by differential soil drainage at the coastal range south of Valdivia, Chile.

Área foliar específica de plántulas de Nothofagus dombeyi y N. nitida pertenecientes a un experimento de trasplantes recíprocos entre dos sitios caracterizados por drenaje diferente en la Cordillera de la Costa, Valdivia, Chile. 
Survival was $100 \%$ for N. nitida and $73.5 \%$ for $N$. dombeyi at the poorly drained site. A resampling test showed that this difference was significant $(\mathrm{P}=0.002$ with 10,000 simulations). Herbivory by livestock prevented us from evaluating survival at the well drained site.

\section{Waterlogging experiment}

Species differed in their responses to gradual waterlogging but not in response to sudden waterlogging (Fig. 4). Foliage loss by $N$. nitida in response to gradual waterlogging was not significantly greater than that in the control treatment (Tukey test, $\mathrm{P}=0.25$ ). In contrast, $N$. dombeyi under gradual waterlogging lost nearly as much foliage mass as plants subjected to sudden waterlogging (Tukey test, $\mathrm{P}=0.06$ ). The mass of total shed leaves in seedlings subjected to gradual waterlogging was $81 \%$ higher in $N$. dombeyi than in N. nitida (Tukey test, $\mathrm{P}<0.091$ ) (Fig. 4) this being the main cause of the difference between species $\left(\mathrm{F}_{1,35}=30.8, \mathrm{P}<\right.$ $0.001)$ and treatments $\left(\mathrm{F}_{2,35}=109.9, \mathrm{P}<0.001\right)$.

Growth differed between waterlogging treatments (Fig. 5) $\left(\mathrm{F}_{2,35}=11.52, \mathrm{P}<0.001\right)$ but not between species $\left(\mathrm{F}_{1,35}=1.8, \mathrm{P}=0.190\right)$.
Plants acclimated to gradual waterlogging grew at a similar rate to the non acclimated plants (Tukey test, $\mathrm{P}=0.108$ ), whereas controls grew more than either plants subjected to sudden or gradual waterlogging (Tukey test, $\mathrm{P}<0.0001$, $\mathrm{P}=0.03$, respectively) and plants subjected to gradual waterlogging. Species responded similarly to the treatments, as indicated by the non-significant interaction of treatment and species $\left(\mathrm{F}_{2,35}=0.309, \mathrm{P}=0.736\right)$.

$\mathrm{RGR}_{\mathrm{H}}$ was inversely correlated with foliage loss in the two species (ANCOVA, $\mathrm{P}=0.003$ ) (Fig. 6). N. nitida was less affected than $N$. dombeyi. The ANCOVA outcome indicated neither a significant difference among species $(\mathrm{P}=0.77)$ nor a significant interaction between species and foliage loss $(\mathrm{P}=0.99)$.

\section{DISCUSSION}

We found that species of contrasting waterlogging tolerance differed significantly in responses to gradual waterlogging, but not in responses to sudden waterlogging. This finding supports the proposal that apparent waterlogging tolerance may depend on the

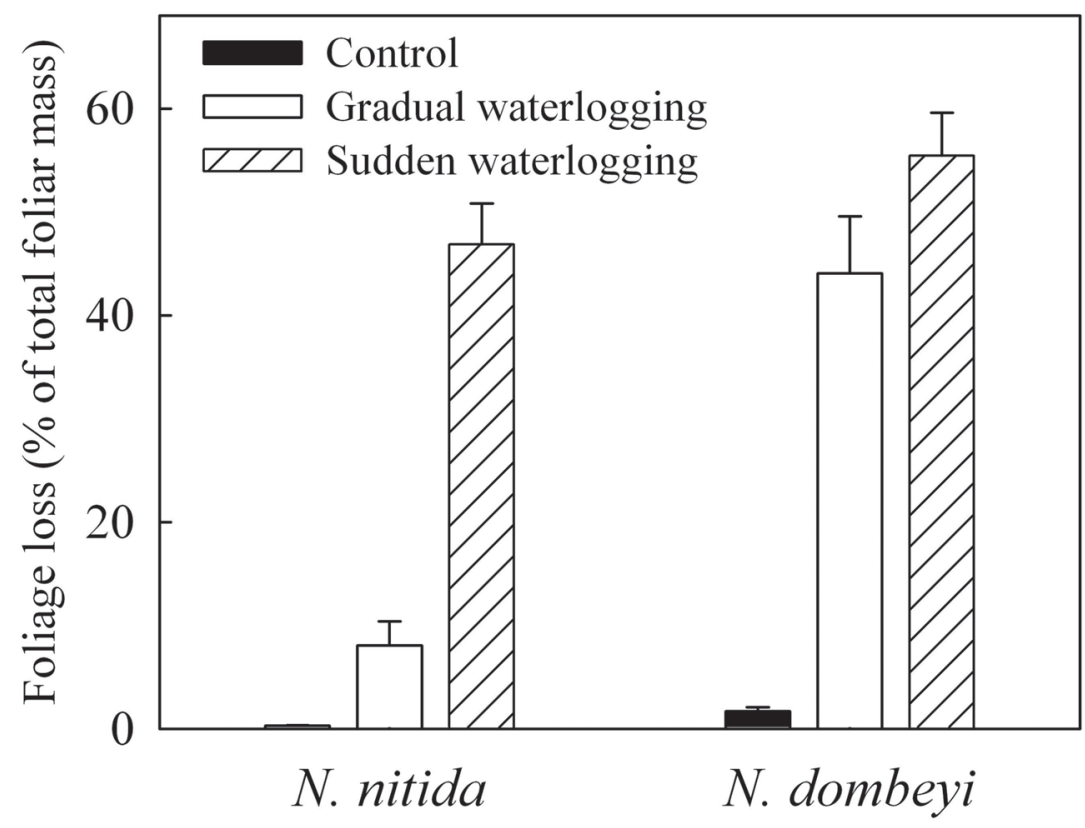

Fig. 4: Final mass of leaves shed of seedlings of Nothofagus dombeyi and N. nitida subjected to a waterlogging experiment for two months. Values are expressed as a percent of the total foliage mass.

Masa final de hojas perdidas en plántulas de Nothofagus dombeyi y N. nitida sujetas a un experimento de anegamiento por dos meses. Valores expresados como porcentaje del peso seco foliar total. 
experimental approach used (Gibbs \& Greenway 2003). Few studies have examined waterlogging simulating natural conditions; among them, the minimal period of full submersion was of 15 days (Talbot et al. 1987, Pryor et al. 2006). Pryor et al. (2006) found that survival of Nothofagus cunninghamii and Eucalyptus obliqua, as well as biomass accumulation of E. obliqua and Acacia melanoxylon, depended on the duration of waterlogging. In contrast, Talbot et al. (1987) found that growth of seedlings of Salix spp. did not vary between waterlogging treatments which differed in the length of flooding period and water-table depth, although plants in all waterlogging treatments did not perform as well as well-drained controls. The similar effects of sudden and gradual waterlogging on $\mathrm{RGR}_{\mathrm{H}}$ in our study (Fig. 5) agrees with the results of Talbot et al. (1987), suggesting that growth is relatively unresponsive to the nature of the onset of waterlogging. However, the different foliage mass loss of Nothofagus nitida between waterlogging treatments (Fig. 4) indicates that differences among species may emerge from submersion pulses of increasing duration. This approach should be considered in future experiments attempting to simulate natural conditions.
Foliage loss responses to gradual waterlogging were consistent with species sorting on soil moisture gradients, and with survival differences on waterlogged sites (Fig. 4). As far as we are aware, the losses of foliage mass never had been previously studied under gradual waterlogging regimes. Foliage mass loss appears to be a typical response of plants to sudden waterlogging reported in short term experiments for different tree species, both evergreen and deciduous, as Quercus spp. (Angelov et al. 1996, Gravatt \& Kirby 1998), Tectona grandis (Osundina \& Osonubi 1989), and Platanus occidentalis (Tang \& Kozlowski 1982). Here, we found that foliage loss response to gradual waterlogging was a better indicator of waterlogging tolerance than responses to sudden treatment.

Higher foliar retention in $N$. nitida than in $N$. dombeyi under gradual waterlogging suggests differences in tolerance to hypoxia or brief periods of anoxia (Fig. 4). Gradual waterlogging gives time for sensing decreases in soil oxygen, allowing biochemical adjustments that avoid an energy deficit. In trees, such adjustments may include the activation of fermentation pathways in roots (Igamberdiev \& Hill 2004) and induction of class 1 haemoglobins (Dordas et al. 2003).

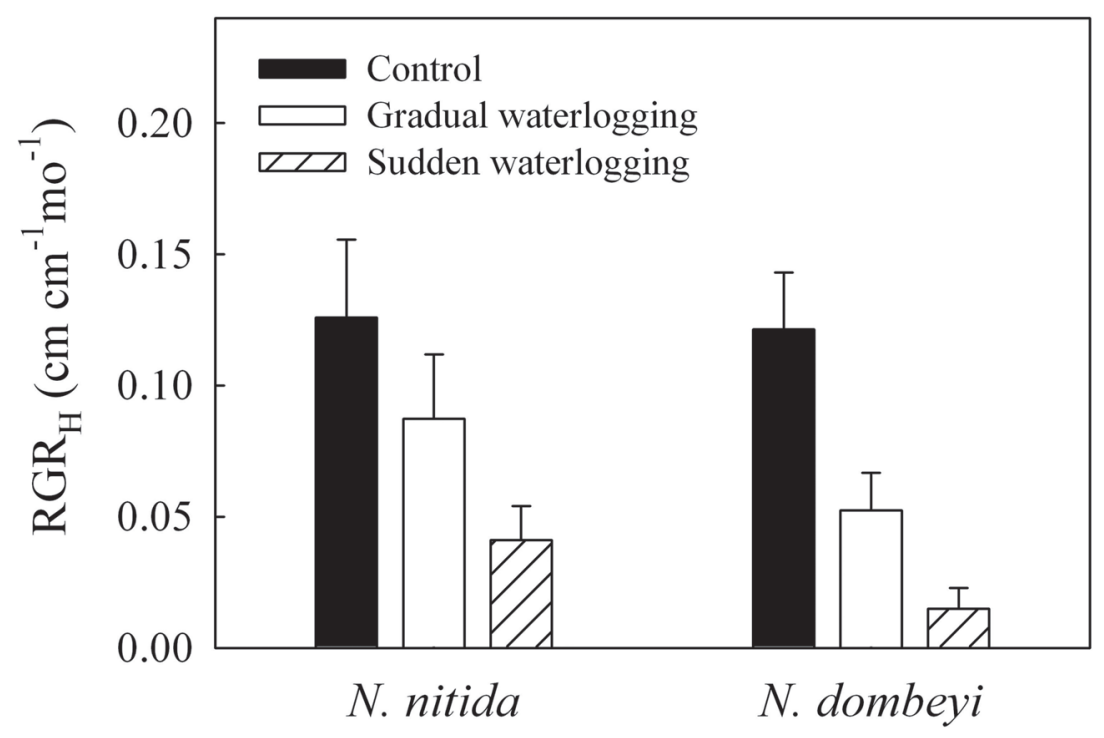

Fig. 5: Relative height growth rate $\left(\mathrm{RGR}_{\mathrm{H}}\right)$ in seedlings of Nothofagus dombeyi and N. nitida subjected to a waterlogging experiment for 2 months.

Tasa de crecimiento relativo en altura $\left(\mathrm{RGR}_{\mathrm{H}}\right)$ de plántulas de Nothofagus dombeyi y $N$. nitida sujetas a un experimento de anegamiento por 2 meses. 


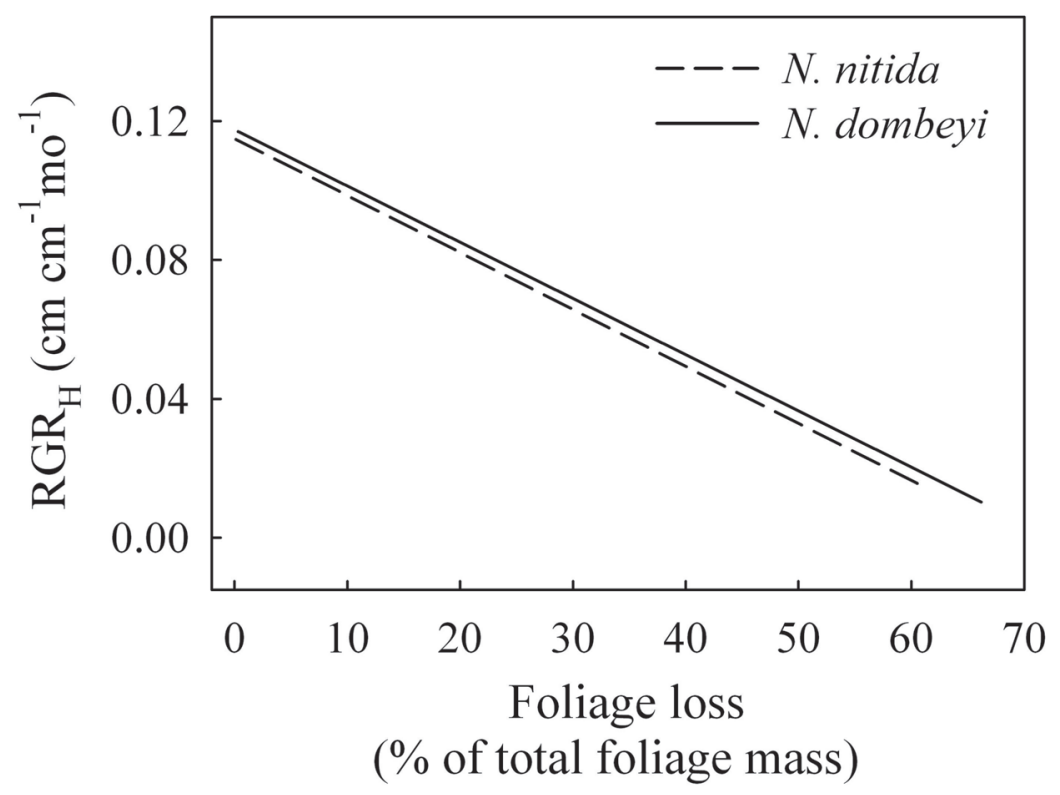

Fig. 6: Linear regressions between relative height growth rate $\left(\mathrm{RGR}_{\mathrm{H}}\right)$ and mass of shed leaves. $N$. nitida $\mathrm{RGR}_{\mathrm{H}}=0,115-(0,002 *$ foliage loss mass $), \mathrm{P}<0,001, \mathrm{r}^{2}=0,3 ; N$. dombeyi $\mathrm{RGR}_{\mathrm{H}}=0,118$ $(0,002 *$ foliage loss mass $), \mathrm{P}<0,001, \mathrm{r}^{2}=0,5$.

Regresiones lineares entre la tasa de crecimiento relativo en altura $\left(\mathrm{RGR}_{\mathrm{H}}\right)$ y la masa de hojas perdidas; $N$. nitida $\mathrm{RGR} \mathrm{H}_{\mathrm{H}}=$ $0,115-(0,002 *$ masa de hojas perdidas $), \mathrm{P}<0,001, \mathrm{r}^{2}=0,3 ; N$. dombeyi $\mathrm{RGR}_{\mathrm{H}}=0,118-(0,002 *$ masa de hojas perdidas $)$, $\mathrm{P}<0,001, \mathrm{r}^{2}=0,5$.

Increment of superoxide dismutase activity was observed in Nothofagus nitida roots subjected to gradual waterlogging but not in $N$. dombeyi roots (Zúñiga-Feest personal communication) suggesting a possible role of radical free scavenging during anoxia. On the other hand, waterlogging tolerance of Myrceugenia exucca and Temu divaricatum, two species from southern Chile, has been linked to the ability to produce adventitious roots and aerenchyma (Debus 1987). Adventitious roots may prevent leaf abscission by increasing the oxidation rate in the rhizosphere region and avoiding toxic leaf concentrations of some minerals (i.e., $\mathrm{Mn}$, Fe) (Osundina \& Osonubi 1989, Blom et al. 1994). We observed adventitious roots in plants of our studied species at the harvest time, but did not quantify them.

In the long term, growth rates and survival of plants at the site characterized by poor drainage confirm that $N$. nitida is more tolerant to this type of soils than $N$. dombeyi (Fig. 2). The higher foliage loss in $N$. dombeyi under waterlogging was reflected in a lower $\mathrm{RGR}_{\mathrm{H}}$ during the short-term experiment than in $N$. nitida (Fig. 4, 5, and 6). Short-term waterlogging events may reduce long-term growth, as it has been observed in Triticum aestivum (Malik et al. 2002) and Quercus spp. (Angelov et al. 1996). For example, the lower growth of $N$. dombeyi with regards to $N$. nitida observed in the transplant at poorly drained site seems to reflect a reduced carbon gain at the whole plant level due to limited foliage area (Fig. 2). Reduced photosynthetic rate per area has been reported for tree species in response to flooding, and such reaction may have also occurred in $N$. dombeyi (Ortuño et al. 2006). Additionally, the decrease in SLA of $N$. dombeyi at the poorly drained site (Fig. 3) may further depress whole-plant carbon gain. It has been demonstrated that the rate of photosynthetic electron transport and the foliar nitrogen content, both expressed per mass unit, decrease along with SLA reductions, leading to lower physiological activity of unit foliar biomass (Niinemets et al. 2002).

Our results suggest that waterlogging tolerance may be better distinguished from responses to gradual submersion of roots than from responses induced by sudden 
waterlogging. Since gradual waterlogging was approached through cycles of increasing duration, acclimation responses could develop, which were reflected in foliar retention (Fig. 4). The higher foliar retention found for $N$. nitida in the two month experiment and its lower mortality in the reciprocal transplant experiment suggests that this short-term response is likely to lead to a long-term advantage. The lower $\mathrm{RGR}_{\mathrm{H}}$ and survival of $N$. dombeyi compared to $N$. nitida at poorly drained soils could explain the exclusion of this species from the sites that are dominated by the latter. For example, the scarcity of $N$. dombeyi in the top of the Coast Range may be explained by the high annual precipitation and the fine textures of soils there, which leads to a situation of frequent waterlogging events (Veblen \& Schlegel 1982). The ecophysiological evidence showed in this study is consistent with the distribution of these two species across a moisture gradient, and may help to better understand some of the mechanisms involved in plant ensembles of the Chilean temperate rain forest.

\section{ACKNOWLEDGMENTS}

We thank The Nature Conservancy and the Reserva Costera Valdiviana for access to the study sites. We also want to thank two anonymous reviewers. This research was supported by FONDECYT (1030663), MECESUP UCO 0214 and the Dirección de Investigación y Desarrollo of Universidad Austral de Chile (S- 200552).

\section{LITERATURE CITED}

ANGELOV MN, S-JS SUNG, RL DOONG, WR HARMS, PP KORMANIK \& CC BLACK (1996) Long and short-term flooding effects on survival and sinksource relationships of swamp-adapted tree species. Tree Physiology 16: 477-484.

BLOM CWPM, LACJ VOESENEK, M BANGA, WMHG ENGELAAR, JHGM RIJNDERS, HM VAN DE STEEG \& EJW VISSER (1994) Physiological ecology of riverside species: adaptive responses of plants to submergence. Annals of Botany 74: 253263.

DEBUS R (1987) Untersuchungen zum Wasserhaushalt von Myrceugenia exsucca und Temu divaricatum in relation zur Morphologie und Anatomie der Wurzel an berflutungstandorten, Liebig Universität, Berlin, Germany. $151 \mathrm{pp}$.
DONOSO CZ (1981) Ecología forestal. El bosque y su medio ambiente. Editorial Universitaria, Santiago, Chile. 369 pp.

DORDAS C, J RIVOAL \& RD HILL (2003) Plant haemoglobins, nitric oxide and hypoxic stress. Annals of Botany 91: 173-178.

GERMAIN V, B RICARD, P RAYMOND \& PH SAGLIO (1997) The role of sugars, hexokinase, and sucrose synthase in the determination of hypoxically induced tolerance to anoxia in tomato roots. Plant Physiology 114: 167-175.

GIBBS J \& H GREENWAY (2003) Mechanism of anoxia tolerance in plants. I. Growth, survival and anaerobic catabolism. Functional Plant Biology 30: 1-47.

GRAVATT DA \& CJ KIRBY (1998) Patterns of photosynthesis and starch allocation in seedlings of four bottomland hardwood tree species subjected to flooding. Tree Physiology 18: 411-417.

HANSEN NE (2001) Efecto del nivel freático de un suelo ñadi sobre las condiciones de crecimiento de una plantación de Eucalyptus nitens Maiden de dos años. Tesis de Ingeniero Forestal, Universidad Austral de Chile, Valdivia, Chile. 112 pp.

HILL R \& G JORDAN (1993) The evolutionary history of Nothofagus (Nothofagaceae). Australian Systematic Botany 6: 111-126.

HOLDGATE MW (1961) Vegetation and soils in the south Chilean islands. Journal of Ecology 49: 559-580.

IGAMBERDIEV AU \& RD HILL (2004) Nitrate, NO and haemoglobin in plant adaptation to hypoxia: an alternative to classic fermentation pathways. Journal of Experimental Botany 55: 2473-2482.

KOZLOWSKI TT (1997) Responses of woody plants to flooding and salinity. Tree Physiology Monograph 1: $1-29$.

LENSSEN JPM, FBJ MENTING \& WH VAN DER PUTTEN (2003) Plant responses to simultaneous stress of waterlogging and shade: amplified or hierarchical effects? New Phytologist 157: 281-290.

MALIK AI, TD COLMER, H LAMBERS, TL SETTER \& M SCHORTEMEYER (2002) Short-term waterlogging has long-term effects on the growth and physiology of wheat. New Phytologist 153: 225-236.

MCQUEEN DR (1976) The ecology of Nothofagus and associated vegetation in South America. Tuatara 22: 38-68.

NIINEMETS Ü \& F VALLADARES (2006) Tolerance to shade, drought and waterlogging of temperate trees and shrubs from the northern hemisphere: tradeoffs, phylogenetic signal and implications for niche differentiation. Ecological Monographs 76: 521-547.

NIINEMETS Ü, A PORTSMUTH \& L TRUUS (2002) Leaf structural and photosynthetic characteristics, and biomass allocation to foliage in relation to foliar nitrogen content and tree size in three Betula species. Annals of Botany 89: 191-204.

ORTUÑO M, Y GARCÍA-ORELLANA, W CONEJERO, M RUIZ-SÁNCHEZ, J ALARCÓN \& A TORRECILLAS (2006) Stem and leaf water potentials, gas exchange, sap flow, and trunk diameter fluctuations for detecting water stress in lemon trees. Trees - Structure and Function 20: 1-8.

OSUNDINA MA \& O OSONUBI (1989) Adventitious roots, leaf abscission and nutrient status of flooded Gmelina and Tectona seedlings. Tree Physiology 5: 473-483.

PIPER FI, LJ CORCUERA, M ALBERDI \& C LUSK (2007) Differential photosynthetic and survival responses to soil drought in two evergreen 
Nothofagus species. Annals of Forest Science 64: 447-452.

PRYOR RJ, NJ DAVIDSON \& DC CLOSE (2006) Waterlogging duration: interspecific comparison of Leptospermum scoparium (Forst et Forst.f.), Acacia melanoxylon (R. Br.), Nothofagus cunninghamii (Hook.) and Eucalyptus obliqua (LHerit). Austral Ecology 31: 408-416.

ROMERO EJ (1986) Fossil evidence regarding the evolution of Nothofagus Blume. Annals of the Missouri Botanical Garden 73: 276-283.

SCHMULL M \& F THOMAS (2000) Morphological and physiological reactions of young deciduous trees (Quercus robur L., Q. petraea [Matt.] Liebl., Fagus sylvatica L.) to waterlogging. Plant and Soil 225: 227-242.

TALBOT RJ, JR ETHERINGTON \& JA BRYANT (1987) Comparative studies of plant growth and distribution in relation to waterlogging. XII. Growth, photosynthetic capacity and metal ion uptake in Salix caprea and S. cinerea ssp. Oleifolia. New Phytologist 105: 563-574.

TANG Z \& T KOZLOWSKI (1982) Physiological, morphological, and growth responses of Platanus occidentalis seedlings to flooding. Plant and Soil 66: 243-255

TANG Z \& T KOZLOWSKI (1984) Water relations, ethylene production, and morphological adaptation of Fraxinus pennsylvanica seedlings to flooding. Plant and Soil 77: 183-192.

Associate Editor: Thomas Kitzberger

Received December 28, 2006; accepted October 31, 2007
THIERS O, V GERDING, A LARA \& C ECHEVERRÍA (2007) Variación de la napa freática en un suelo ñadi bajo diferentes tipos vegetacionales, X Región, Chile. In: Gonda H, M Davel, L Gabriel \& OA Picco (eds) Libro de actas de ecoreuniones. Primera reunión sobre forestación en la Patagonia: 259-266. Centro de Investigación y Extensión Forestal Andino Patagónica (CIEFAP), Esquel, Chubut, Argentina.

VEBLEN TT \& FM SCHLEGEL (1982) Reseña ecológica de los bosques del sur de Chile. Bosque (Chile) 4 : 73-115.

VEBLEN TT, C DONOSO, T KITZBERGER \& AJ REBERTUS (1996) Ecology of southern Chilean and Argentinian Nothofagus forests. In: Veblen TT, RS Hill \& J Read (eds) The ecology and biogeography of Nothofagus forests: 293-353. Yale University Press, New Haven, Connecticut, USA.

WATERS I, PJ KUIPER, C WATKIN E \& H GREENWAY (1991) Effects of anoxia on wheat seedlings: interaction between anoxia and other environmental factors. Journal of Experimental Botany 42: 1427-1435.

WEINBERGER P (1973) The regeneration of the Araucano-patagonic Nothofagus species in relation to microclimatic conditions. Tuatara 22: 233-244.

XIA J-H \& PH SAGLIO (1992) Lactic acid efflux as a mechanism of hypoxic acclimation of maize root tips to anoxia. Plant Physiology 100: 40-46. 